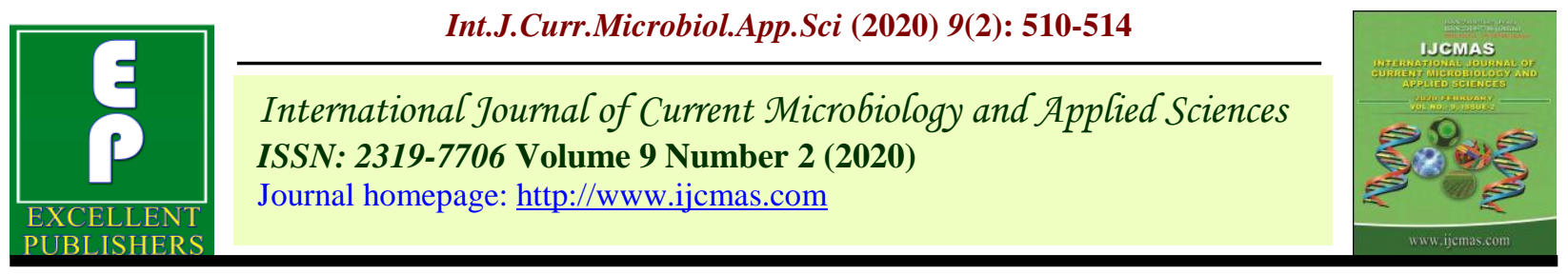

Original Research Article

https://doi.org/10.20546/ijcmas.2020.902.062

\title{
Yield and Yield Parameters of Transplanted Rice Genotypes under Different Irrigation Regimes in TBP Area
}

\author{
G. Narappa*, B. G. Mastanreddy, A. S. Channabasavanna, \\ N. Ananda and Mahanthashivayogayya
}

Department of Agronomy, College of Agriculture

University of Agricultural Sciences, Raichur- 584104, Karnataka, India

*Corresponding author

Keywords

Rice genotypes, Irrigation Regimes, AWD, Yield

Article Info

Accepted:

08 January 2020

Available Online:

10 February 2020

\section{A B S T R A C T}

A Field experiment was conducted at Agricultural Research Station, Gangavathi, University of Agricultural Sciences, Raichurto know the yield performance of transplanted rice genotypes under different water regimes in TBP area during Kharif2018. The experiment was laid out in split plot design with three replications. There were three irrigation regimes as main plot treatments and five rice genotypes as sub-plot treatments. The results concluded that, among the different irrigation regimes, higher grain (7294 $\mathrm{kg} \mathrm{ha}^{-1}$ ), straw (8210 $\mathrm{kg} \mathrm{ha}^{-1}$ ) yield, number of panicles $\mathrm{m}^{-2}(560.2)$, panicle length $(23.7 \mathrm{~cm})$, number of filled grains panicle ${ }^{-1}(214.6)$, panicle weight $(3.4 \mathrm{~g})$ and test weight $(20.7 \mathrm{~g})$ were recorded with alternate wetting and drying as compared to other treatments. Among the rice genotypes, GNV-11-09 recorded higher grain (7575 kg ha $\left.{ }^{-1}\right)$ and straw $\left(8645 \mathrm{~kg} \mathrm{ha}^{-1}\right)$ yield as compared to other rice genotypes.

\section{Introduction}

India is the second largest country for rice production and rice continues to hold the key to sustained food production by contributing 20-25 per cent of agriculture and assures food security for more than half of the total population (Anon., 2012). Rice (Oryza sativa L.) is the world's most important crop and is a staple food for more than half of the world's population. Asia accounts for 60 per cent of the global population, about 92 per cent of the world's rice production and 90 per cent of global rice consumption. In India, rice is grown over an area of 42.94 million hectares, with annual production of about 112.90 million tons and productivity being 2585 $\mathrm{kgha}^{-1}$ (Anon., 2018). India is the second largest country for rice production and rice continues to hold the key to sustained food production by contributing 20-25 per cent of agriculture and assures food security for more 
than half of the total population (Anon., 2012).Water is the most limited natural resource of late, due to failure of rains and over exploitation of ground water. The dwindling water resources reveal a grim situation for lowland puddle rice cultivation. To overcome this problem and increase the rice grain production to meet the food security we need to develop novel technologies that will sustain or enhance the rice production by increasing irrigation efficiencies. If rice is grown under traditional conditions, farmers resort to continuous submergence irrigation resulting in enormous wastage of water and lower water use efficiency. Hence, it becomes essential to develop and adopt strategies and practices for more efficient use of water in rice cultivation. The dominant system of rice cultivation in Asia is transplanting, where in field is kept continuously flooded with 5 to 10 $\mathrm{cm}$ water throughout the growing season (Bouman and Tuong, 2001), which ultimately leads to water and nutrient losses through percolation, evaporation and seepage.

The alternate wetting and drying (AWD) irrigation aims at reducing water input and enhancing water productivity while maintaining optimum grain yield of rice (Tabbal et al., 2002). Zhi (2001) observed the impact of AWD on water use and found that irrigation water use was reduced by 7-25 per cent with the AWD technique.

Lack of appropriate genotypes and water management practice is a limiting factor for successful rice cultivation under shrinking water condition. Appropriate agronomic management is thus, a prerequisite to exploit full potential of the available resources, to realize the maximum possible benefits from the suitable genotypes under different irrigation regimes. Hence, it is essential to develop appropriate package of practices for successful cultivation and yield maximization. In this study, attempts have been made to test the possibility of optimizing and improving growth of rice genotypes by the alternation in water management practices. Keeping these facts in view, the present investigation entitled "Yield and Yield Parameters of Transplanted Rice Genotypes under Different Irrigation Regimes in TBP Area" was conducted during kharif 2018.

\section{Materials and Methods}

A field experiment was conducted at Agricultural Research Station (ARS), Gangavathi, University of Agricultural Sciences, Raichur, Karnataka during Kharif 2018 to study the growth parameters of transplanted rice genotypes under different irrigation regimes comprised of three Iirrigation regimes viz., ( $\mathrm{I}_{1}$ : Alternate wetting and drying (AWD), $\mathrm{I}_{2}$ : Saturation maintenance (Moisture at hair crack) and $\mathrm{I}_{3}$ : Continuous flooding levels) as main factors and five rice genotypes $\left(\mathrm{V}_{1}: \mathrm{GGV}-05-01, \mathrm{~V}_{2}\right.$ : MTU-1010, V 3 : GNV-11-09, V 4 : GNV-10-89 and $\mathrm{V}_{5}$ : RNR-15048), as sub factors was laid out in split plot design with fifteen treatment combinations and three replications. The soil of the experimental site was medium deep black clay in texture. The land was ploughed once with mould-board plough and cultivated. Puddling was done twice followed by passing leveler and weeds were picked. Plots were created as per the plan and land leveling was done within plot for uniform distribution of water. Alternate wetting and drying (AWD) was carried out through the use of Bouman tube or field water tube. These are polythene tubes of $20 \mathrm{~cm}$ diameter and $35 \mathrm{~cm}$ length. On the lower $15 \mathrm{~cm}$ portion small holes were made at 3-4 cm interval and the remaining 20 $\mathrm{cm}$ was left as it is. The lower $15 \mathrm{~cm}$ portion was inserted into the puddle soil leaving 20 $\mathrm{cm}$ above soil surface and the soil inside the tube was removed. When plot was irrigated the water level inside the tube and outside remains at the same level. AWD was 
practiced whenever water level inside the tube fells below $15 \mathrm{~cm}$ (by measuring with a scale).Irrigation was done upto $5 \mathrm{~cm}$ standing water and this cycle was practiced up to panicle initiation. From panicle initiation to flowering $3 \mathrm{~cm}$ standing water was maintained and there after again AWD was maintained. Saturation consists of maintaining moisture at hair crack level. Here plots were ponded to 5 $\mathrm{cm}$ standing depth allowed to recede to small hair crack stage followed again by ponding to $5 \mathrm{~cm}$ water. This was continued up to panicle initiation stage and $3 \pm 2 \mathrm{~cm}$ after wards and continuous flooding implemented by maintaining standing water level of $5 \mathrm{~cm}$ continuously throughout crop growth period.Fertilizers were applied in the form of urea, diammonium phosphate (DAP) and muriate of potash (MOP) for supplying nitrogen, phosphorus and potassium at the rate of 200:100:100 N, $\mathrm{P}_{2} \mathrm{O}_{5}$ and $\mathrm{K}_{2} \mathrm{O} \mathrm{kg} \mathrm{ha}{ }^{-1}$. A pre-emergence weedicide bensulfuron methyl+ pretilachlor $(6.6 \% \mathrm{G})$ when applied at the rate of $10 \mathrm{~kg} \mathrm{ha}^{-1}$ by mixing with sand and broadcasted uniformly at 3 DAT (Days after transplanting) and followed by hand weeding at 20 days after transplanting. During the experimental period, the crop was slightly affected by leaf blast and was immediately controlled by spraying tricyclazole @ $0.6 \mathrm{~g} \mathrm{l}^{-1}$ using $5001 \mathrm{ha}^{-1}$ of spray solution. The crop was harvested at maturity as the ear heads turned brownish colour coupled with straw turned to yellowish colour. Observations on growth parameters of rice were recorded at 30, 60, 90 DAT and at harvest from five randomly selected plants. Standard techniques were used for recording observations. The data collected from the experiment at different growth stages and at harvest were subjected to statistical analysis as described by Gomez and Gomez (1984).The level of significance used for ' $\mathrm{F}$ ' was $\mathrm{P}=0.05$. Critical Difference $(\mathrm{CD})$ values were calculated at 5 per cent probability level, where the $F$ test was found to be significant.

\section{Results and Discussion}

The results concluded that, among the different irrigation regimes, alternate wetting and drying recorded significantly higher plant dry matter at harvest $\left(83.1 \mathrm{~g} \mathrm{hill}^{-1}\right)$, number of panicles (560.2) and panicle length (23.7), panicle weight $(3.4 \mathrm{~g})$ and test weight $(20.70$ g) as compared to continuous flooding (Table $2)$. With respect to different rice genotypes, GNV-11-09 recorded significantly higher dry matter production hill $^{-1}$ at harvest $(79.9 \mathrm{~g})$, number of panicles (584.7) and panicle length (24.), panicle weight (3.5 g) and test weight $(25.6 \mathrm{~g})$ as compared to other rice genotypes, but remained on par with MTU-1010 (4.7, 25.2, 57.5 and $77.6 \mathrm{~g} \mathrm{hill}^{-1}$ at 30, 60, $90 \mathrm{DAT}$ and at harvest, respectively). On the other hand significantly lower dry matter production hill $^{-1}$ (3.8, 19.6, 49.6 and $69.1 \mathrm{~g}$ hill $^{-1}$ at 30, 60, 90 DAT and at harvest, respectively) was recorded in RNR-15048.

Interaction effect of different irrigation regimes and rice genotypes at all growth stages of crop (30, 60, 90 DAT and at harvest) was found non-significant with respect to dry matter production in transplanted rice.

The higher dry matter production in case of alternate wetting and drying was mainly attributed to production of more number of tillers hill ${ }^{-1}$ and higher leaf area which were the resultant of optimum moisture and aeration conditions as observed in the case of alternate wetting and drying. These results are in conformity with the finding of Sudhakar et al., (2006). The higher dry matter production observed in the case of genotypes GNV-11-09 and MTU-1010 were similarly attributed to production of more number of tillers and high leaf area hill $^{-1}$.The data indicated that among irrigation treatments, alternate wetting and drying recorded significantly higher grain $\left(7294 \mathrm{~kg} \mathrm{ha}^{-1}\right)$ and straw $\left(8210 \mathrm{~kg} \mathrm{ha}^{-1}\right)$ yield as compared to continuous flooding (Table 3 ). 
Table.1 Plant height, Number of leaves hill ${ }^{-1}$, No. of tillers $\mathrm{m}^{-2}$, Leaf area, LAI and dry matter production as influenced by irrigation regimes and genotypes in transplanted rice

\begin{tabular}{|c|c|c|c|c|c|c|}
\hline Treatments & $\begin{array}{c}\text { Plant } \\
\text { height } \\
(\mathrm{cm}) \text { at } \\
\text { harvest }\end{array}$ & $\begin{array}{l}\text { Number of } \\
\text { leaves hill } \\
\text { at } 60 \mathrm{DAT}\end{array}$ & $\begin{array}{c}\text { No. of } \\
\text { tillers } \\
\mathrm{m}^{-2} \text { at } \\
\text { harvest }\end{array}$ & $\begin{array}{l}\text { Leaf area } \\
\left(\mathrm{cm}^{2} \text { hill }^{-1}\right) \\
\text { at } 60 \text { DAT }\end{array}$ & $\begin{array}{c}\text { Leaf area } \\
\text { index } \\
(\text { LAI) at } \\
\text { 60 DAT }\end{array}$ & $\begin{array}{c}\text { Dry matter } \\
\text { production } \\
\left(\mathrm{g} \mathrm{hill}^{-1}\right) \text { at } \\
\text { harvest }\end{array}$ \\
\hline \multicolumn{7}{|c|}{ Irrigation regimes (I) } \\
\hline$I_{1}: A W D$ & 105.0 & 85.4 & 700 & 1366 & 6.83 & 83.1 \\
\hline $\mathbf{I}_{2}$ : Saturation & 103.7 & 78.1 & 698 & 1251 & 6.26 & 73.5 \\
\hline $\mathbf{I}_{3}$ : Continuous flooding & 102.2 & 71.0 & 683 & 1147 & 5.74 & 68.1 \\
\hline S.Em. \pm & 0.6 & 2.0 & 5.1 & 38 & 0.15 & 3.0 \\
\hline $\mathrm{CD}(p=0.05)$ & 2.6 & 7.6 & 16 & 118 & 0.58 & 9.6 \\
\hline \multicolumn{7}{|c|}{ Genotypes (V) } \\
\hline$V_{1}: G G V-05-01$ & 101.6 & 74.0 & 695 & 1226 & 6.13 & 73.2 \\
\hline $\mathrm{V}_{2}:$ MTU-1010 & 106.2 & 83.0 & 714 & 1266 & 6.33 & 77.6 \\
\hline$V_{3}:$ GNV-11-09 & 103.6 & 87.2 & 722 & 1346 & 6.73 & 79.9 \\
\hline$V_{4}:$ GNV-10-89 & 100.6 & 75.6 & 696 & 1258 & 6.29 & 74.6 \\
\hline$V_{5}:$ RNR-15048 & 106.3 & 71.2 & 641 & 1178 & 5.89 & 69.1 \\
\hline S.Em. \pm & 0.8 & 3.1 & 8 & 37 & 0.18 & 1.1 \\
\hline $\mathrm{CD}(p=0.05)$ & 2.4 & 8.99 & 23 & 107 & 0.54 & 3.2 \\
\hline
\end{tabular}

With respect to different rice genotypes, GNV-11-09 produced significantly higher grain $\left(7575 \mathrm{~kg} \mathrm{ha}^{-1}\right)$ and straw $\left(8645 \mathrm{~kg} \mathrm{ha}^{-1}\right)$ yield as compared to other rice genotypes, except MTU-1010 (7545 and $8535 \mathrm{~kg} \mathrm{ha}^{-1}$, respectively) and GNV-10-89 (7187 and 8076 $\mathrm{kg} \mathrm{ha}^{-1}$, respectively) where in it remained on par and significantly lower grain yield (6286 and $6969 \mathrm{~kg} \mathrm{ha}^{-1}$, respectively) was recorded in RNR-15048. The genotypes GNV-11-09 recorded $5.12 \%$ higher grain yield than the popular GNV-10-89 (7187 $\left.\mathrm{kg} \mathrm{ha}^{-1}\right)$ and $17 \%$ higher grain yield than RNR-15048.

The results concluded that, among the irrigation regimes, alternate wetting and drying method was found superior performance with respect to yield and yield attributes of transplanted rice genotypes (GNV-11-09) as compared to other methods of irrigation regimes and genotypes.

\section{References}

Anonymous, 2012, Agricultural Statistics at glance, Directorate of Economics and Statistics. Department of Agriculture and Co-operation, Ministry of Agriculture, Government of India.

Anonymous, 2018, Directorate of Economics and Statistics. www.indiastat.com

Bouman, B. A. M. and Toung, T. P., 2001, Field water management to save water and increase its productivity in irrigated low land rice. Agric. Water Manage, 49: 11-30.

Gomez, K. A. and Gomez, A. A., 1984, Statistical Procedures for Agricultural Research, $2^{\text {nd }}$ Edition. Awiley InterScience Publications, New York (USA). Lafitte, H. R., Guan, Y., Sheng, S. and Li, Z. K., 2006, Performance of rice genotypes under aerobic soil. J. Expt. Bot., 58(2): 
169-175.

Sudhakar, P. C., Singh, J. P., Yogeshwar Singh and Raghavendra Singh, 2006, Effect of graded fertility levels and silicon sources on crop yield, uptake and nutrient-use efficiency in rice (Oryza sativa L.). Indian J. Agron., 51(3): 186-188.

Tabbal, D. F., Bouman, B. A. M., Bhuyian, S. I., Sibayan, E. B. and Sattar, S. I., 2002, On-farm strategies for reducing water input in irrigated rice; case studies in the Philippines. Agric. Water Manage.,
56: 93-112.

Virdia, H. M. and Mehta, H. D., 2008, Integrated nutrient management in transplanted rice (Oryza sativa L.). Rice Res., 2: 2.

Wang, H., Boumman, B. A. M. and Msea, P. F., 2007, Aerobic rice in China. IRRI Report, 2007.

Zhi, M., 2001, Water efficient irrigation and environmentally sustainable irrigated rice production in China. Wuhan Univ., Wuhan, China. pp. 237-245.

\section{How to cite this article:}

Narappa, G., B. G. Mastanreddy, A. S. Channabasavanna, N. Ananda and Mahanthashivayogayya. 2020. Yield and Yield Parameters of Transplanted Rice Genotypes under Different Irrigation Regimes in TBP Area. Int.J.Curr.Microbiol.App.Sci. 9(02): 510-514. doi: https://doi.org/10.20546/ijcmas.2020.902.062 